\title{
The Practice and Assessment of College English Flipped Classroom Teaching in Medical Schools
}

\author{
Yuefang Sun \\ Foreign Language Department, Jining Medical College, Jining, Shandong 27200, China
}

\begin{abstract}
To better meet the demand of our society for the new compound talents with high abilities of intercultural communication, education reforms have been under way for a long time. College English teaching has been explored and perfected in terms of teaching contents and teaching model. This essay has practiced and assessed college English flipped classroom teaching, by carrying out teaching experiments, retrospectively comparing the results college English examinations of clinical medical students of Grade 2014 to 2017, and undertaking the questionnaire. It is concluded that college English flipped classroom teaching is feasible and is of many advantages, but there are still many problems which can't be neglected. The practice and assessment of college English flipped classroom teaching mentioned in this essay will be significant to English teaching development.
\end{abstract}

Index Terms - intercultural communication, compound talents, flipped Classroom

\section{INTRODUCTION}

Accompanying the process of globalization speeding up, more and more international cooperation has been under way, which is an opportunity as well as a challenge for college students. Apart from doing well in their chosen profession, they have to master English very well, which refers to not only the basic English knowledge but also the ability of practicing it.

In Medical universities, English course is nothing but one of the public optional courses, is an interdisciplinary subject, which is always forced to give way to medical curriculums, teachers fulfilling the heavy teaching task in limited periods. Thus English teaching and learning has been going on in the traditional way, in which teachers dominate the classroom activities while students receive what the teacher is teaching passively. As a result, English teaching in the traditional method has made students lose interest in English studying and deprived teachers of sense of achievement and academic authority. There is a desperate need for changing in College English teaching.

\section{THE CONCEPT OF FLIPPED CLASSROOM}

Flipped Classroom is a kind of informationized teaching model in the era of Big Data, a big revolution in teaching model. It's said that the thought of Flipped Classroom teaching was first put forward in the early nineteenth century by Thayer, Sylvanus, general of West Point. To Ackoff and Greenberg, teaching in the traditional method focuses on teaching instead of learning which should be the goal of teaching, because teaching aims at imparting knowledge to students while it is learning that can inspire one's creativity and wisdom ( Russell. L. Ackoff and Daniel Greenberg, 2008). As the earliest practitioner, Salman Khan, an American, released the teaching videos one section after another on YouTube, which aroused people's attention promptly.

Flipped Classroom is a kind of teaching model, relying on information technology and through the Internet platforms to realize the goal of improving students' autonomous learning ability. By reversing the order of knowledge transfer and knowledge internalization in the traditional teaching and learning model, flipped classroom model aims at improving the teaching and learning efficiency. Moreover, it can break the obstacles of time and space, as effected in the traditional model, help provide personalized teaching and multiple interactive modes, and extend the classroom instruction without burdening students with extra learning periods.

Due to the increasing numbers of internet platforms and the implementation of flipped classroom model in Khan Academy, the new model became prevalent in American and successfully attracted the attention of educators all over the world. It has deeply promoted the integration of information technology and school education.

\section{The Status Quo of FlipPed Classroom Model in China}

In China, the research on flipped classroom model started in 2013, and has become the focal point of teaching reform in China since 2015. Many educators has devoted to combining the essence of flipped classroom model with local environment, and many elementary schools has implement this new model in their teaching and learning system, which has proved it works. With the successful implementation in primary schools, it began reforming the teaching and learning models in the universities. Many educators has empirically probed into the flipped classroom model in College English, such as, Cui Yanhui and Wang Yi has pointed out that the combination of flipped classroom model and 
information technology can make up some shortcomings and disadvantages of college English teaching and learning in the traditional model, which can result into the high English learning efficiency of college students (Cui Yanhui and Wang Yi,2014); Zhao Bing and He Gaoda did some research on how to apply the flipped classroom model to the graduate English learning of the minority university, and proved that flipped classroom model can help improve the their ability of independent learning(Zhao Bing and He Gaoda). There are many research on it, so is the practice of it. But there is few implementation of it in college English class, especially in medical universities.

In view of this, the author, an experienced English teacher in Jining Medical College of China, reformed college English teaching model in her classes, having optimized the course contents and renewed teaching method, which put the idea of Flipped Classroom into practice. To further improve teaching activities and the ability of handling the problems in teaching reform, the author has analyzed retrospectively the College English test paper of clinical majors of Grade 2014 to Grade 2017, objectively evaluated the teaching quality and efficiency, and conducted the questionnaire survey among part of clinical majors about flipped classroom model, so this research will also has great reference value for the further reform of college English teaching.

\section{The Research on Flipped Classroom Model in College English Teaching in Medical University}

The Object and Methods of the Research

1. The basic research materials

One, the results of the final examinations of medical majors from Grade 2014 to Grade 2017 in Jining Medical University; Two, a new edition of Comprehensive College English Course I (second edition) as the unified teaching materials published by Shanghai foreign language education press; Three, the total periods is 36 , finished in 18weeks with 2 periods per week.

2. The objects of the research

About 1500 medical majors were chosen to be the objects of this research, who were divided into two groups: control group(about 600 students of Grade 2014 and Grade 2015) and experimental group (about 900 students of Grade2016 and Grade 2017); while a total of 185 students received the questionnaire.

3. The methods of the research

a. The reform of College English teaching

Before the reform, College English teaching in Jining medical University went on in the traditional way: It is the teacher who dominated the class activities while what students could do was just received passively what the teacher taught in class with less interaction, resulting from the limited teaching hours and heavy teaching task. As a result, College English teaching in the traditional way was dull and tedious to students, and the unified teaching materials and teaching process make it difficult to make teacher teach students according to their own level. Consequently, there is poor attendance and little teaching efficiency. So the traditional teaching model has gradually deprived teachers of academic authority and a sense of achievement, and the flame of students' learning interest has burned out.

While in flipped classroom model, College English teaching and learning takes on a new look. Flipped Classroom Model has completely reversed the traditional teaching and learning model, and inverted the whole teaching structure: Before class, teachers will collect the materials, from book and online, make a careful selection, edit them into videos, and then release them online, while students will watch them before class, think about what the videos are saying, and put forward questions where they can't understand; In class, students will make a deep understanding by collaborating with classmates in discussion with the guidance and supervision of their teacher; after class, students will review what they learned by finishing their assignments given by their teacher.

Flipped classroom model makes English class active again and rekindles students' enthusiasm for learning English. Since materials before class offered by teachers include both knowledge from textbook and web-based text and video, the subject matter content is rich and vivid (Clark,1983). While in class, through the discussion and communication of student-teacher and student-student, students' initiative an creativity have been greatly aroused, and it help develop students' skills of critical thinking (Zhang Jinlei, 2013). Flipped classroom model makes the independent learning of students come true.

b. The questionnaire survey of flipped classroom model

In the academic year of 2017 to 2018, the author conducted a questionnaire survey of flipped classroom model among clinical majors in Jining Medical University. A total of 185 clinical majors received the questionnaire, among which 183 valid questionnaires were taken back on the spot, 2 questionnaires invalid. The questionnaire has put forward questions from three dimensions in cognition, behavior and emotion. The contents include students' cognition of flipped classroom model, their expectation to it, advantages and disadvantages of it, and so on.

c. data processing

This research has statistically analyzed the data, applied One-Way ANOVA to the analysis of the character of data (such as the distribution of the test score, mean difference, and standard deviations), and conducted the two-two comparison among means By SNK-q. The significance test was 0.05

4. The results

a. College English test final results of medical majors from Grade 2014 to Grade2017

In Jining Medical College, College English Test result consist of two parts: the result of theoretical test result and the 
regular grades, among which the regular grades are graded by their teacher according to their attendance and other behavior in class of clipped classroom model. College English Test result came from the test paper with a full mark of 100 , which is composed of writing $(15 \%)$, listening $(35 \%)$, reading comprehension(35\%) and translation(15\%), and account for $70 \%$ of College English Test result, while the regular grades account for $30 \%$ of it.

The Analysis of the Theoretical Test Result

The theoretical test is usually a computer test in Jining Medical College. The numbers of students in the tables refer to the students attending the test per test. Form Table I, it can be easily seen that there is no obvious difference between four theoretical tests in terms of the difficulty, reliability and discrimination of the test; And there is a trend of marked improvement: the over pass rate and excellent rate have improved a lot while there a significant difference between theoretical test results $(\mathrm{F}=29.416, \mathrm{P}=0.0000<0.01)$. We can see the final results of College English test of Grade 2014 to Grade 2017 from Table II to Table V. From those histograms, we can see that when the author carried on teaching in the traditional teaching method, there is no significant difference between the final results of Grade 2014 and Grade 2015 : there were more people failing the exam and fewer with high marks, and the results showed negative skewers distribution and the overall level is low. In contrast, when the author used the flipped classroom model in Classes of Grade 16 and Grade 2017, there is marked improvement of the finals results of students, and a significant different $(\mathrm{F}=19432, \mathrm{P}=0.0000<0.01)$. The details can be seen from table I to Table V.

TABLE I

ANALYSIS OF COMPUTER TEST RESUlTS OF MEDICAL MAJORS FROM GRADE 2014 TO GRADE 2017

\begin{tabular}{ccccccccccc}
\hline Class & Numbers & $\begin{array}{c}\text { Highest } \\
\text { Mark }\end{array}$ & $\begin{array}{c}\text { Lowest } \\
\text { mark }\end{array}$ & $\begin{array}{c}\text { Average } \\
\text { Score }\end{array}$ & $\begin{array}{c}\text { Standard } \\
\text { Deviation }\end{array}$ & $\begin{array}{c}\text { Pass } \\
\text { Rate }\end{array}$ & $\begin{array}{c}\text { Excellence } \\
\text { Rate }\end{array}$ & Difficulty & Reliability & Discrimination \\
\hline 2014 级 & 320 & 83 & 23 & 43.4 & 10.2 & 46 & 1 & 0.56 & 0.83 & 0.25 \\
2015 级 & 280 & 89 & 30 & 44.2 & 10.2 & 57 & 3 & 0.62 & 0.84 \\
2016 级 & 450 & 90 & 30 & 48.3 & 11.3 & 73 & 10 & 0.65 & 0.88 \\
2018 级 & 414 & 92 & 31 & 50 & 12 & 95 & 21 & 0.67 & 0.90 \\
\hline
\end{tabular}

TABLE II

ANALYSIS OF COLLEGE ENGLISH FINAL RESULTS OF MEDICAL MAJORS OF GRADE 2014

\begin{tabular}{|c|c|c|c|c|c|c|c|c|c|c|}
\hline \multicolumn{2}{|c|}{ 课序号 } & \multicolumn{2}{|c|}{5} & 人数 & 215 & \multirow{2}{*}{\multicolumn{2}{|c|}{$\frac{\text { 实考人数 }}{\text { 均方差 }}$}} & 215 & 缺考人数 & 0 \\
\hline 平均分 & 57.8 & 最高分 & 85 & 最低分 & 30 & & & 11.4 & 期望值 & 5 \\
\hline \multicolumn{2}{|c|}{ 平均分 } & \multicolumn{2}{|c|}{ 人数 } & \multicolumn{2}{|c|}{ 百分率(\%) } & \multirow{2}{*}{$\begin{array}{l}55 \\
50 \\
45 \\
40\end{array}$} & & & & \\
\hline \multicolumn{2}{|c|}{$\geqslant 90$ 分 } & \multicolumn{2}{|c|}{0} & \multicolumn{2}{|c|}{0.0} & & & & & \\
\hline \multicolumn{2}{|c|}{ 80-89分 } & \multicolumn{2}{|c|}{4} & \multicolumn{2}{|c|}{1.8} & $\begin{array}{r}35 \\
-30\end{array}$ & & & & \\
\hline \multicolumn{2}{|c|}{ 70-79分 } & \multicolumn{2}{|c|}{28} & \multicolumn{2}{|c|}{13} & 20 & & & & \\
\hline \multicolumn{2}{|c|}{ 60-69分 } & \multicolumn{2}{|c|}{76} & \multicolumn{2}{|c|}{35.4} & 10 & & & & \\
\hline \multicolumn{2}{|c|}{$<60$ 分 } & \multicolumn{2}{|c|}{107} & \multicolumn{2}{|c|}{49.8} & 0 & 290 & $80-89$ & $60-69$ & $<60$ \\
\hline
\end{tabular}

TABLE III

ANALYSIS OF COLLEGE ENGLISH FinAl RESUltS OF MEDICAL MAJORS OF GRADE 2015

\begin{tabular}{|c|c|c|c|c|c|c|c|c|c|c|}
\hline \multicolumn{2}{|c|}{ 课序号 } & \multicolumn{2}{|c|}{5} & 人数 & 207 & \multirow{2}{*}{\multicolumn{2}{|c|}{$\frac{\text { 实考人数 }}{\text { 均方差 }}$}} & 206 & 缺考人数 & 1 \\
\hline 平均分 & 58.6 & 最高分 & 89 & 最低分 & 33 & & & 10.3 & 期望值 & 5 \\
\hline \multicolumn{2}{|c|}{ 平均分 } & \multicolumn{2}{|c|}{ 人数 } & \multicolumn{2}{|c|}{ 百分率(\%) } & \multirow{2}{*}{$\begin{array}{l}55 \\
50 \\
45 \\
40 \\
35\end{array}$} & & & & \\
\hline & & & & & & & & & & \\
\hline \multicolumn{2}{|c|}{$80-89$ 分 } & \multicolumn{2}{|c|}{7} & \multicolumn{2}{|c|}{3.3} & $\begin{array}{r}35 \\
-\quad 30\end{array}$ & & & & \\
\hline \multicolumn{2}{|c|}{ 70-79分 } & \multicolumn{2}{|c|}{41} & \multicolumn{2}{|c|}{19.9} & 20 & & & & \\
\hline \multicolumn{2}{|c|}{ 60-69分 } & \multicolumn{2}{|c|}{67} & \multicolumn{2}{|c|}{32.5} & 10 & & & & \\
\hline \multicolumn{2}{|c|}{$<60$ 分 } & \multicolumn{2}{|c|}{91} & \multicolumn{2}{|c|}{44.2} & 0 & $>90$ & $80-89$ & $70-79$ & $<60$ \\
\hline
\end{tabular}


TABLE IV

ANALYSIS OF COLLEGE ENGLISH FINAL RESULTS OF MEDICAL MAJORS OF GRADE 2016

\begin{tabular}{|c|c|c|c|c|c|c|c|c|c|c|}
\hline \multicolumn{2}{|c|}{ 课序号 } & \multicolumn{2}{|c|}{6} & \multirow{2}{*}{$\begin{array}{c}\text { 人数 } \\
\text { 最低分 }\end{array}$} & \multirow{2}{*}{$\begin{array}{l}213 \\
37\end{array}$} & \multirow{2}{*}{\multicolumn{2}{|c|}{$\frac{\text { 实考人数 }}{\text { 均方差 }}$}} & \multirow{2}{*}{$\begin{array}{l}213 \\
9.6\end{array}$} & \multirow{2}{*}{$\frac{\text { 缺考人数 }}{\text { 期望值 }}$} & \multirow{2}{*}{$\frac{0}{5}$} \\
\hline 平均分 & 62.9 & 最高分 & 91 & & & & & & & \\
\hline \multicolumn{2}{|c|}{ 平均分 } & \multicolumn{2}{|c|}{ 人数 } & \multicolumn{2}{|c|}{ 百分率(\%) } & \multirow{2}{*}{$\begin{array}{l}55 \\
50 \\
45 \\
40 \\
35\end{array}$} & & & & \\
\hline \multicolumn{2}{|c|}{$\geqslant 90$ 分 } & \multicolumn{2}{|c|}{3} & \multicolumn{2}{|c|}{1.4} & & & & & \\
\hline \multicolumn{2}{|c|}{ 80-89分 } & \multicolumn{2}{|c|}{23} & \multicolumn{2}{|c|}{10.8} & -30 & & & & \\
\hline \multicolumn{2}{|c|}{ 70-79分 } & \multicolumn{2}{|c|}{53} & \multicolumn{2}{|c|}{24.9} & 20 & & & & \\
\hline \multicolumn{2}{|c|}{ 60-69分 } & \multicolumn{2}{|c|}{79} & \multicolumn{2}{|c|}{37.1} & 10 & & & & \\
\hline \multicolumn{2}{|c|}{$<60$ 分 } & \multicolumn{2}{|c|}{55} & \multicolumn{2}{|c|}{25.8} & 0 & 290 & 80.89 & $60-69$ & $<60$ \\
\hline
\end{tabular}

TABLE V

ANALYSIS OF COLLEGE ENGLiSH FinAl RESUlTS OF MEDICAL MAJORS OF GRADE 2017

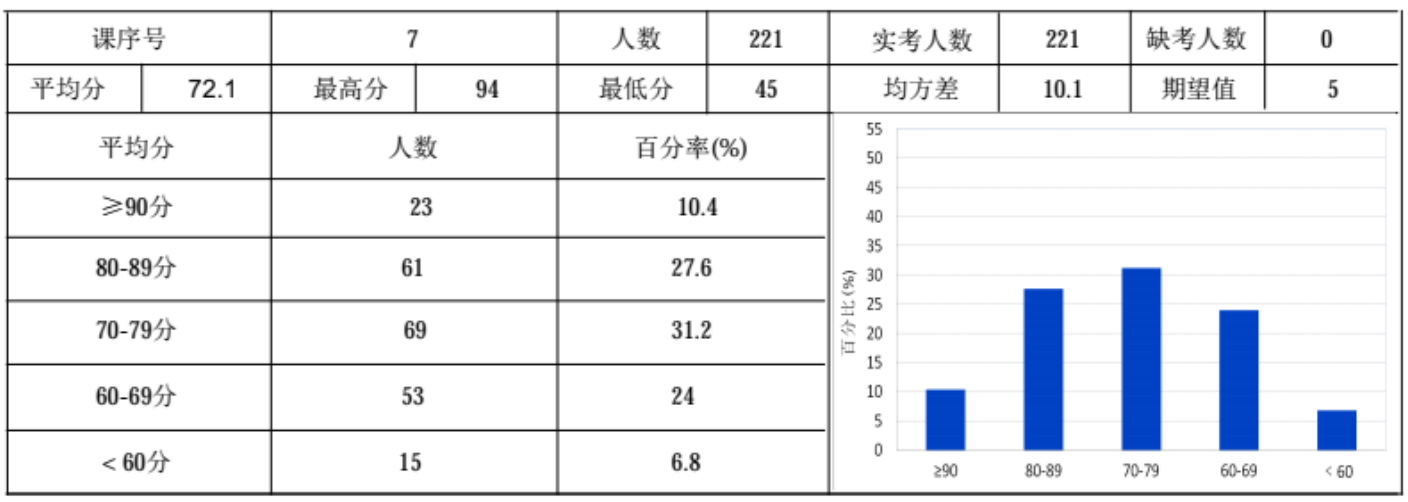

b. The results of questionnaire

Most of students who have attended the questionnaire survey hold the opinion that it is necessary to replace the traditional teaching method with flipped classroom model, and show a clear recognition that it can help them pass College English Test Band Four. It can be seen from the results of questionnaire that most students agree on the application of flipped classroom model to College English teaching and learning, show a great interest in it, and are confident of improving their comprehensive abilities of English. Meanwhile, they have put forward some constructive suggestions, summarized as follows: First, to improve the interest of learning English by reforming the tradition teaching method; second, to improve the comprehensive ability of English in listening, speaking, reading, writing and translating; Third, to add some contents about medical English and postgraduate English to the regular English teaching; Fourth, to further implement the flipped classroom model(abbreviated to FCM in Table VI) in English teaching. The content of questionnaire have been summarized into Table VI.

TABLE VI

RESUlTS OF THE QUESTIONNAIRE ABOUT COLLEGE ENGLISH FLIPPED ClASSROOM MODEL [N=181,N(\%)]

\begin{tabular}{llll}
\hline Content of questionnaire & Agree & Not Sure & Oppose \\
\hline The cultivation of the idea of FCM & $155(85.64)$ & $17(9.39)$ & $9(4.97)$ \\
The necessity of the application of it to English class & $161(88.95)$ & $15(8.29)$ & $5(2.76)$ \\
The possibility to improve students' learning interest & $158(87.29)$ & $19(10.50)$ & $4(2.21)$ \\
The ability to improve students' comprehensive ability & $171(94.48)$ & $10(5.52)$ & $0(0.00)$ \\
The ability to cultivate students' creative thinking & $160(88.40)$ & $12(6.63)$ & $9(4.97)$ \\
The meaning to help train new compound talents & $173(95.58)$ & $5(2.76)$ & $3(1.66)$ \\
\hline
\end{tabular}

\section{DiscusSION}

Generally speaking, in medical universities, College English, as a basic subject and an important part of higher education, plays an important role in educating compound talents due to its outstanding features of humanism and instrumentality. But the traditional teaching method used now in English class has presented an obstacle to all-round development of college students and has stood in the way of improving students' language proficiency. Thus, it is quite necessary to reform the traditional teaching model and implement information-based teaching to meet the social demand for new compound talents.

It's true that the research was conducted among parts of students, so the results of the final test and questionnaire are of a certain one-sidedness, but they are still more truly reflect the changes before and after teaching reform. After 
analyzing the examination results, we can easily notice that there is a sharp contrast of the results between before the reform and after it, showing obviously ascending trend, which mainly owes to flipped classroom model. Students has made a rapid progress in English learning, which strongly reveals the fact that flipped classroom model exert a tremendous fascination on students and has aroused their enthusiasm for learning English. According to the analysis of the questionnaire, it can be concluded that most students accept this kind of new teaching model and think they have benefitted from it. Of course, we should seriously take the suggestions students put forward on flipped classroom teaching into consideration. We should treat the teaching reform objectively, and adjust teaching plan and contents in time to make it fit into the development and changes more flexibly.

\section{A. The Feasibility of the Application of Flipped Classroom Model to English Class}

With the rapid development of information technology, there are more both online and offline teaching resources available and popularization of mobile devices (such as, computer, mobile phones, PAD, and so on), which provides software guarantee for the application of flipped classroom model. In flipped classroom, college students are the main body, who, compared with senior high school students, are more mature with better consciousness, much stronger initiatives and self-control. What's more, the application of flipped classroom model to College English class is kind of the summary of practical experience---many educators, home and abroad, have done much research and exploration of it, and conducted some preliminary teaching practices, which are not completely perfect, but still good proof of its feasibility.

\section{B. The Implementation Strategy of Flipped Classroom Model}

\section{To advocate the idea of flipped classroom}

Numerous studies have fully proved that at present flipped classroom model is the kind of teaching method more suitable to accord with the time demands. Before applying it to College English classes, teachers should convey accurately its basic concept to students, enabling students to understand its process, advantages, and its demand for the cooperation of students and teachers, which aims at let students accept it and be willing to take part in it. If we fail these tasks, students will only treat it as a new thing, which can attract their attention for a moment but can't really arouse their interest in participating in it.

2. To better use the tool of content curation

Content curation is the activity in which people make full use of their wisdom to gather, organize and online present content related to a particular theme or topic(Niu Xuefeim and Hu Jianping 2015). With the tool of content curation, teachers can select, condense, and transfer worthy and valid contents from the vast areas of unlimited knowledge, and then teachers will put them into video and release them on the learning platform, which avoid burdening students by making a clear distinction between easy contents and difficult ones.

3. To choose carefully network platform and manage it properly

Nowadays, there are many network platforms, such as, QQ, WeChat, e-shoolbag, and the like. But there are fewer of them can be used as an educational platform. In Jining Medical College, Blendspace, a tool of content curation, and Edmodo, a social learning platform, are perfectly combine together, which makes it possible to flipped classroom can go on smoothly. With Blendspace, teachers can set up curriculums, easily add or cancel teaching materials, and even insert their own comments. Blendspace enables teachers to supervise students' learning process and check their learning efficiency with the test released on the platform, which achieves the integration, assessment and sharing of educational resources. As a social learning platform, Edmodo can help teacher organize collaborative learning between students. The combination of Blendspace and Edmodo has really made information-base education come true.

4. To properly control class activities

Here the word "Properly" means that teachers should let students be the protagonists of class activities while properly handling the time and pace of activities to make sure that there are as many people as possible to get the chance to express themselves in class, which can greatly help arouse students' initiative in leaning English.

5. To set up multiple evaluation system

Multiple evaluation system should be set up to fairly and fully evaluate the learning effectiveness of each student. The system consists of three parts: diagnostic evaluation in the early period of learning; formative evaluation during the learning process; summative evaluation at the end of learning.

6. To make summary and feedback in time

Teachers should check the contents and forms of flipped classroom to make it better, evaluate students' performances in class and give them feedbacks in time so that they can know their learning effectiveness and adjust their learning manners if necessary, which is a metacognitive process helping students make progress in learning eventually.

\section{Problems of Teaching Reform and Its Countermeasures}

Every teaching model is a powerful and fragile tool (Joyce, B., Weil, M., \& Calhoun, E. , 2004). There is no model of teaching perfect enough to fit into all situations. Though in the teaching practice of flipped classroom model there is certain achievement, there are also some problems which can not be ignored. The problems and its countermeasures have been listed out as follows.

1. The limitations of experimental subjects 
In this research, the author chose 1500 clinical majors of Grade 2014 to Grade 2017 in Jining Medical College as the experimental subjects, which can suffice to prove the positive effect of flipped classroom model to clinical majors, but it can't confirm other evidence that it works among other medical majors, such as, nursing majors, preventive medical majors, applied psychological majors, and so on. Thus, we'd better reform College English class among more other medical majors to get more experimental data, which can greatly help endow teaching reform with features of medical university to find out the best way of reforming.

2. The need for more contents

Compared with traditional teaching method, Flipped classroom model enrich students with more extra-curricular knowledge and present them in diverse ways, but most of them are still based on and related to contents of the textbook. There are some students with higher levels in English who want to achieve the goal of pursuing a further study after graduate, home or abroad. To meet their demand, teachers should introduce more related information and give students different assignments according to their own level and need.

3. Serious lack of English teachers with high-level information technology

To a great extent, the serious shortage of English teachers is one of the main reasons why flipped classroom model can't be applied to all medical majors. Luckily, problems can be solved like this: (1) medical universities should invest more money in introducing talent teachers and in teaching training. (2) teachers should consciously improve their abilities of information technology and try to use technological devices effectively.

\section{CONCLUSION}

The implementation of flipped classroom model to College English class in medical university is a win-win strategy, which can help improve both the teaching level of English teachers and the comprehensive abilities of medical majors. Since every teaching model fit into a certain culture and society, we need constantly improve and perfect it to meet the new demands of our society.

\section{REFERENCES}

[1] Clark, R. (1983). Reconsidering Researching on Learning from Media. Review of Education Research, Vol.4, 445-459.

[2] Cui Yanhui and Wang Yi. (2014). Flipped Class Model and Its Application to College English Teaching. Technology Enhanced Chinese Education, Vol.11, 116-120.

[3] Joyce, B., Weil, M., \& Calhoun, E. (2004). Models of Teaching (7th ed.). Boston: Allyn and Bacon.

[4] Niu Xuefeim and Hu Jianping. (2015). Content Curation Platform LessonPaths: a Preliminary Exploration of Their Application in Flipped Classroom. Asia Pacific Education, Vol.29, 297-297

[5] Russell. L. Ackoff and Daniel Greenberg. (2008). Turning Learning Right Side Up: Putting Education Back on Track . America: Pearson Prentice Hall.

[6] Zhang Jinlei. (2013). The Exploration and Analysis of the Critical factors in Flipped Classroom Model. Distance Education in China. Vol.10, 59-64.

[7] Zhao Bing and He Gaoda. (2015). Explorative Research on Flipped Classroom in Graduate English of the Minority University. Technology Enhanced Foreign Language Education, Vol.166, 165-169.

Yuefang Sun, born in Jining, Shandong Province in 1979. She received the bachelor degree from Shandong Science and Technology University in 2002, and the master degree from Qufu Normal University in 2012.

She is currently a lecturer in School of Foreign Languages, Jining Medical University, Jining, China. She has been teaching in Jining Medical University for seventeen years; courses taught include Integrated English, and Traditional Chinese Cultures (English version); her research interests include Applied Linguistics and second language acquisition. 